\title{
Conflict of Laws and Functionally Restricted Substantive Rules
}

\author{
Rodolfo De Nova*
}

GINCE THE IMPACT of legal positivism on private international law at $N$ the end of the nineteenth century engendered or strengthened the national or local approach to the choice of law, conflicts scholars have become interested in describing the conflicts rules actually in force in each jurisdiction. To this end, they have also attempted to bring together and articulate those conflicts rules that might be scattered and half-concealed among the substantive rules constituting the bulk of national statutes and codes.

Occasionally, the keenest surveyors came upon some strange specimens: provisions that were undoubtedly substantive in character, yet sported certain appendages that made them look suspiciously like undeveloped conflicts rules. Such provisions were indeed substantive rules, but carried a limitation as to their scope which looked very much like a special rule of conflict of laws. Professor Nussbaum calls such dispositions "spacially conditioned internal rules," because they are apphicable to the factual situations they prima facie govern only if the facts are related to a given country by some connection stated or implied by the rules themselves or specifically established for them-connections very similar to those used by the usual conflicts rules. An example fashioned by Franz $\mathrm{Kahn}^{2}$ is a special statute of limitations for debts, the payment of which should be effected abroad. Here the foreign locus solutionis is a condition of the applicability of that particular statutory rule: It himits the type of debts to which the rule applies, the social phenomena it controls. Moreover, the place of payment may well be a connecting factor in a current rule of private international law on contracts.

The primary function of a national system of conflicts rules is generally considered to be that of defining the field of application of the local substantive rules. It is easy to infer therefrom that the restrictions explicitly or implicitly placed on the applicability of a substantive rule by the rule itself or by an additional provision ad hoc, amount to the formulation of an apposite conflicts rule: a special one, "made to measure" for that individual substantive provision. However, if this inference is made, the opponents of renvoi-or, from the viewpoint of positive law, those

\footnotetext{
* Dr. jur., University of Pavia, Italy (1928); Dr. rer. pol., University of Pavia (1930); Professor of Public and Private International Law, University of Pavia.

1 Nussbauds, Principles of Private Internattonat Law 40-43 (1943).

$21 \mathrm{Kathi}$, Abirandlungen zus internationalen Privatrecht 27 (1928).
} 
who work under a legal system that rejects renvoi, as does Italian law ${ }^{3}-$ will find themselves in a quandary whenever a substantive rule of that sort happens to be a part of the applicable foreign law and would govern the case at hand if that rule were not so peculiarly restricted: shall they take into account this limitation and disregard the rule, or disregard the limitation and apply the rule? If the opponents of renvoi choose the second alternative, they will disfigure that rule by making it cover a situation which was not meant to be within its reach. Thus, they will not be applying that particular foreign law but something else, so that the result will be neither foreign nor local law, but a distortion of the applicable foreign law through the imterference of the local conflicts rule. On the other hand, if they take the first alternative, they will contradict themselves or betray their own legal order by bowing to renvoi contrary to their given premise prohibiting consideration of foreign confiicts rules.

Those who ascribe to the "foreign court theory"-or to renvoi in general, be it only occasionally and for practical or positive law reasonswould not be troubled by any sucl alternative. This is indeed one situation where the renvoi theory is to be welcomed because here it is incapable of ill effects or of encountering difficulties of its own: The applicable foreign law is applied as it is, with its substantive rules and all their ingrained limitations.

The anti-renvoinsts may find, on closer inspection, that they do not really have any reason to worry about those foreign substantive rules which but for their own limitations would govern a given case. Applying a foreign "self-limiting" substantive rule on its own terms-namely, only when the case at hand perfectly fits its schema-is not paying obeisance to foreign rules of private international law, which is the essence of renvoi. It is simply applying that substantive rule of the competent legal order which does fit the facts of the given case-as those facts are seen by that legal order. Consequently, legal materials operative outside that order are not used as they are under remission or transmission, or the "open offer" formula, ${ }^{4}$ in a word, under renvoi. Here one stays within the applicable foreign legal order and chooses among its substantive provisions the one that most closely fits the factual situation. Therefore, neither prorenvoi or anti-renvoi bias, nor positive law commitments, should affect the solution of the present difficulty, since it is not really a question of taking into account or disregarding foreign conflicts rules, or more precisely, foreign rules on private international law. It is simply a question

\footnotetext{
${ }^{3}$ See Crv. Code art. 30 (preliminary Dispositions) (Italy 1942).

"See Raeburn, The "Open Offer" Formula and the Renvoi in Private International Law, 25 BRTT. YB. INT'I L. 211 (1948).
} 
of finding, within the "competent" foreign law, the correct rules of decision.

The ultimate choice is to be made among the substantive provisions which directly ${ }^{5}$ constitute the foreign legal order chosen by the reference rules of the forum; and this can be a very difficult task when the criteria used by the foreign law to specify the range of its various provisions are not clearly stated or must be inferred from the "purpose" of the substantive provisions themselves. Perhaps much of what has passed and still passes for debate on problems of conflict of laws in the United States is at bottom this sort of difficulty. A few recent American cases will exemplify this.

One illustration is Kaufman v. American Youth Hostels, Inc. ${ }^{6}$ The following are the facts as given by Professor Bramerd Currie in his coinment on the case:

In 1956 a fifteen-year-old girl, apparently residing in New York, enrolled in that State for a western tour to be conducted by American Youth Hostels, a New York corporation conceded to be an eleemosynary institution. The venture included a climb of Mt. Hood, in Oregon, in the course of which the girl fell to her death. Her father, also apparently a resident of New York, sued in that State in his own right and as administrator of the estate. One of the defenses was that the defendant, as a charity, was immune. That defense having been abolished by New York law, the defendant's rehance was necessarily upon the law of Oregon. The Appellate Division sustained this defense on the simplistic ground that the law of the place of injury determines liability in tort, and the Court of Appeals affirmed.7

Professor Currie surmises that "Oregon has an overriding policy of fostering and conserving the funds of cliaritable enterprises," and quotes this passage from a decision of an Oregon court: "From the beginning, the overriding public policy of this state ... has been to protect the assets of charitable institutions from use for any purpose other than that for which they were organized." But then Professor Currie remarks that since Oregon had no conceivable interest in conserving the assets of a foreign corporation, at least where the corporation was not "doing business" in Oregon, the Oregon rule protecting the assets of charitable institutions was concerned only with Oregon eleemosynary institutions, or,

5 That is, without contribution by the conflicts rules of the foreign legal order or importation of legal materials from other "countries."

${ }^{6} 6$ App. Div. 2d 223, 177 N.Y.S.2d 587 (1958), modified on other grounds, 5 N.Y.2d 1016, 158 N.E.2d 128, 185 N.Y.S.2d 268 (1959).

7 Currie, Setected Essays on the Conflict of Laws 558 (1963).

$8 I d$., at 559 .

O Landgraver v. Emanuel Lutheran Charity Bd., 203 Ore. 489, 493-94, 280 P.2d 301, 302 (1955). 
at most, with foreign corporations of this type doing business in Oregon. Hence, the Oregon defense of charitable immunity should not have been applied in Kaufman, and the bereaved plaintiff should have prevailed.

I agree that the plaintiff should have prevailed, but the question is under what law? The result argued for by Professor Currie by reference to the substantive law of New York, in opposition to the choice of Oregon law made by the New York courts, is also supported by Oregon law if only it had been correctly applied. The applicable Oregon law was not the rule protecting charitable enterprises, but the more general policy protecting and indemnifying the victims of tortious conduct. This is undoubtedly a general policy of Oregon law which is occasionally circumscribed by the special Oregon immunity rule in favor of charitable institutions of the State of Oregon. A New York charitable enterprise, being outside the province of the special immunity rule of Oregon-assuming that this rule was not meant for the protection of foreign corporations as well-was prima facie within the purview of the general policy rule of Oregon, provided that the legal system of Oregon had "legislative jurisdiction" on the subject matter according to the conflicts rules of the New York forum. This jurisdiction was present in the instant case-which came under the traditional principle of lex loci delicti commissi, recognized at the time by the New York courts-because the issue was liability in tort, and both the wrongful conduct and the injury occurred in Oregon. However, the courts of New York either disregarded or misunderstood the interplay of Oregon substantive rules in giving an unjustified prominence to the exceptional immunity rule over the basic policy on tortious responsibility. Since the same general policy was also part of New York law, ${ }^{10}$ the case did not raise a real question of conflict of laws at all. Therefore, it was superfluous to choose between the substantive rules in point belonging to the legal systems concerned.

Another American decision that can be used as an illustration of the problem of "functionally-restricted substantive rules" is Babcock v. Jackson. ${ }^{11}$ The judgment of the Court of Appeals of New York in this case has been widely commented upon in the Umited States ${ }^{12}$ as being a further step away froin the old and indiscriminating conflicts rule on torts that stresses the paramount importance of the locus delicti. It lias also been

10 "Both New York and Oregon have policies of protection and indemnity for the victim of tortious conduct." CURRIE, op. cit. supra note 7, at 558-59.

11 Babcock v. Jackson, 12 N.Y.2d 473, 191 N.E.2d 279, 240 N.Y.S.2d 743 (1963).

12 See, e.g., the outstanding comments by such American conflicts authorities as Professors Cavers, Cheatham, Currie, Ehrenzweig, Leflar, and Reese in 63 Corusa. L. Rev. 1212 (1963). For careful foreign appraisals see Drion, The Lex Loci Delicti in Retreat: A Foreigner's Remarks on Babcock v. Jackson, in FESTSCERIFT FÜR OTTO RIESE 225 (1964); Vitta, La responsabilita da illecito nei conflitti di leggi negli Stali Uniti: in margine ad alcune recenti sentenze, 19 DIRITTo InTERNazionale 212 (1965). 
praised by the proponents of new methods of dealing with conflicts matters, who are as much in agreement in criticizing the old-fashioned approacli as they are in disagreement with one another in planning for the future and caring for the present. It comes almost as a shock, therefore, to find that the Babcock decision offered reasons for self-satisfaction to all innovators! However, even under the traditional "jurisdiction-selective" conflicts theory and the lex loci delicti rule its conclusion is wellfounded. Once more, I give the facts as reported by Professor Currie:

In Babcock v. Jackson the plaintiff and the defendant, both residents of Rochester, New York, set out from Rochester on a trip that took them into the Canadian province of Ontario, the plaintiff being a guest in the defendant's automobile. In Ontario the car went out of control and collided with a stone wall, seriously injuring the plaintiff. When she sued in New York, the defendant pleaded the Ontario guest statute, a Draconian provision without parallel in any of the United States. (It says:) "... the owner or driver of a motor vehicle, other than a vehicle operated in the business of carrying passengers for compensation, shall not be hable for any loss or damage resulting from bodily injury to, or death of, any person being carried in, or upon, or entering or getting into, or alighting from such motor vehicle."13

The action was dismissed by the court of special term, and the appellate division affirmed the judgment. But the court of appeals reversed, mainly for the reason that the lex loci delicti commissi was not controlling and instead the lex fori applied. Judge Fuld-speaking for the court over the dissent of Judge Van Voorhis, concurred in by Judge Scileppi-remarked inter alia that "the concern of New York is unquestionably the greater and more direct and that the interest of Ontario is at best minmal."14 This "balancing-of-state-interests approach," which was liailed by the progressive wing of American conflicts lawyers, does not concern us now. For present purposes, it is more rewarding to relate one of the arguments produced by Mr. Justice Halpern of the appellate division to support his dissent. I resort again to Professor Currie's narrative:

Mr. Justice Halpern provided at least five distinct bases on which a different result [from that reached by the court, namely, the application of the Ontario statute] might be rested: ...5. The doctrine of renvoi: i.e., that the rule that the law of the place of injury governs is a reference to the whole law of that State, including its choice-of-law rules. Investigation might reveal that Ontario itself would not apply its statute to an accident involving only non-residents. ${ }^{15}$

This passage clearly sliows the equivocation in considering as an instance of renvoi the refusal to apply a provision of the applicable foreign

13 CURRIE, op. cit. supra note 7, at 722.

14 Babcock v. Jackson, 12 N.Y.2d 473, 482, 191 N.E.2d 279, 284, 240 N.Y.S.2d 743, 750 (1963).

15 CuRRIE, op. cit. supra note 7, at 722-23. (Emphasis added.) 
law that originally bears a limitation preventing it from governing the case at hand. As argued by the commentators on Babcock, ${ }^{10}$ and particularly by Professor Currie, ${ }^{17}$ the Ontario non-paying guest statute seemed to be directed-in purpose if not in terms-to the protection of Ontario insurance companies against "the fraudulent assertion of claims by passengers in collusion with the drivers."18 $\mathrm{Mr}$. Justice Halpern concluded on this point that "In the light of this purpose, it is apparent that the interest of Ontario in the enforcement of its legislative policy is limited to accidents involving Ontario residents (as defendants)."10 Once it is accepted that the "Draconian provision" of the Ontario Highway Traffic Act, given a functional interpretation, did not by implication extend to an accident that happened outside Ontario, affected foreign travelers only, and did not concern any Ontario insurance company, the rule of decision in a case such as Babcock v. Jackson would be supplied-in a legal system still faithful to the conflicts principle that places liability ex delicto under the lex loci delicti commissi-by the general policy rule of the Ontario law of torts. Since under that rule relief to the victim as against the tortfeasor would very likely be granted, the conclusion that the lex fori provides, lacking any Dracomian statute, would be reached. In Babcock, therefore, once the true content of Ontario law-namely, the respective scope of its substantive rules (common law of torts, Draconian statute)-is ascertained, there is no real conflict of laws, because the only two legal systems that are possibly governing, those of Ontario and New York, take the same position on the point in issue.

Unfortunately, I repeat, it is usually far from easy to ascertain, in the light of the dubious or manifold purpose of a substantive rule, ${ }^{20}$ which cases fall within its domain and which do not. Another fundamental difficulty is to set apart the "spacially conditioned substantive rules" themselves. ${ }^{21}$ To this end, it must be remembered that they are special provisions, usually set down by statute (lex specialis) as an exception to a general written or unwritten legal rule. They relate as such to a narrow set of facts, partly and characteristically defined by a "spacial" condition of applicability, namely, by one or more apposite "connecting factors."

${ }^{10}$ See, e.g., Comments on Babcock v. Jackson, A Recent Development in Conflict of Lawes, 63 CoLuMr. L. REv. 1212 (1963).

17 CURRIE, op. cit. supre note 7, at 724-25.

$18 \mathrm{Id}$, at 724 .

10 Babcock v. Jackson, 17 App. Div. 694, 696, 230 N.Y.S.2d 114, 117 (1962).

20 See Drion, supra note 12 , at 235.

21 On such rules and their place in conflict of laws, see De Nova, $I$ conflitti di leggi $e$ le norme con apposita delimitazione della sfera di efficacia, 13 DIRTTTO INTERNazTonare 13 (1959), French translation in 1 Metanges MaURY 377 (1960); Francescakis, Quelques precisions sur les regles de conflits de lois, 55 ReVUe CRITIQUE DE DroIt Internationas PrIve 1 (1966); Graulich, Regles de confil et regles d'application immediate, 2 Mezanges Daben 629 (1963). 